\title{
Forestry Water Quality Index - A planning tool for the assessment and communication of the impacts of forestry activities on water quality
}

\author{
by Annette Tobin ${ }^{1}$, Amir Ali Khan², Haseen Khan², Len Moores ${ }^{3}$ and Jim Taylor ${ }^{4}$
}

\begin{abstract}
The assessment of the impacts of forestry activities on water quality is a critical component of forestry management and planning, especially when watersheds are being used for different water uses by different stakeholders. Traditional methodologies for assessing these impacts, while accurate, often do not take into account the intended use of water. Water quality data are inherently technical and are not conducive to communication to all stakeholders-especially the public. There is a need for a communications-based assessment tool that assesses the impact of forestry activities on water quality from the perspective of different water uses. This paper describes the development and application of such a tool, the Forestry Water Quality Index (FWQI). The FWQI has been developed specifically to capture, evaluate and communicate the impact of forestry activities on water quality to multiple stakeholders. Initially based on the Canadian Council of Ministers of the Environment's Water Quality Index, the FWQI was specifically adapted for applications in forestry management. Details of this adaptation and its methodology are outlined. Case studies from Newfoundland and Labrador illustrate the use of the FWQI for communication, performance evaluation, and planning and technical data analysis. The FWQI tool has the ability to compare pre- and post-forestry water quality data (communication), determine the effectiveness of best management practices (performance evaluation), predict water quality after forestry activities (planning) and evaluate seasonal variations in water quality (data analysis). These components provide useful information for the evaluation of the effects of forestry activities on water quality and to ensure sustainable forest management. It can be utilized by both forestry and water resources management to ensure sustainable development of the forestry sector.
\end{abstract}

Key words: FWQI, sustainable forest management, water quality, Newfoundland and Labrador

\section{RÉSUMÉ}

L'évaluation des impacts des activités forestières sur la qualité de l'eau représente un élément important de la planification et de l'aménagement forestiers, surtout lorsque les bassins versants sont utilisés de différentes façons par plusieurs intervenants. Les méthodologies traditionnelles d'évaluation de ces impacts, bien que précises, ne considèrent pas dans bien des cas l'utilisation prévue de l'eau. Les données sur la qualité de l'eau sont essentiellement techniques et ne se prêtent pas facilement à des échanges avec tous les intervenants, notamment le public. Il est donc nécessaire d'avoir un outil d'évaluation reposant sur les échanges qui évaluerait l'impact des activités forestières sur la qualité de l'eau pour différentes utilisations de cette dernière. Cet article décrit l'élaboration et l'application d'un tel outil, l'Indice de la qualité de l'eau en foresterie (IQEF). L'IQEF a été élaboré spécifiquement pour identifier, évaluer et faire état de l'impact des activités forestières sur la qualité de l'eau face à un public composé de plusieurs intervenants. Élaboré à partir de l'Indice de la qualité de l'eau du Conseil canadien des ministres de l'Environnement, l'IQEF a été adapté précisément pour les interventions en aménagement forestier. Les détails de cette transformation et de cette méthodologie sont présentés. Des études de cas en provenance de Terre-Neuve et du Labrador illustrent l'utilisation de l'IQEF au niveau des communications, de l'évaluation de la performance ainsi que de la planification et de l'analyse des données techniques. L'IQEF a la capacité de comparer les données de la qualité de l'eau antérieures et postérieures (communications), de déterminer l'efficacité des meilleures pratiques d'aménagement forestier (évaluation de la performance), de prédire la qualité de l'eau à la suite des activités forestières (planification) et d'évaluer les variations saisonnières de la qualité de l'eau (analyse des données). Ces éléments apportent de l'information utile pour l'évaluation des effets des activités forestières sur la qualité de l'eau et la mise en place d'un aménagement forestier durable. Il peut être utilisé autant pour l'aménagement forestier que pour l'aménagement des ressources hydriques dans le but d'assurer le développement durable du secteur forestier.

Mots clés : IQEF, aménagement forestier durable, qualité de l'eau, Terre-Neuve et Labrador

\footnotetext{
${ }^{1}$ Department of Environment and Conservation, Government of Newfoundland and Labrador, PO Box 2006, Corner Brook, Newfoundland A2H 6J8. E-mail: AnnetteTobin@gov.nl.ca

${ }^{2}$ Department of Environment and Conservation, Government of Newfoundland and Labrador, PO Box 8700, St. John's, Newfoundland A1B $4 \mathrm{~J} 6$.

${ }^{3}$ Department of Natural Resources, Government of Newfoundland and Labrador, PO Box 2006, Fortis Tower, Corner Brook Newfoundland A2H $6 \mathrm{~J} 8$.

${ }^{4}$ Western Newfoundland Model Forest, PO Box 68, University Drive, Corner Brook Newfoundland A2H $6 \mathrm{C} 3$.
} 


\section{Introduction}

Forestry is one of the important natural resources in Canada that has contributed to the socio-economic development of many communities across the country, as well as to strengthening the national economy. There have been concerns, however, regarding the environmental impacts of forest management on water quality and the environment. During the last 20 years, studies were undertaken to assess forestry-related environmental impacts. The outcomes of these studies were published in the form of technical reports and other publications, and thus the information was limited to technical audiences. The general public either did not have access to this information or the information was too technical to be understood. In spite of substantial efforts by the scientific community to document and understand the impact of forestry operations, the public perception about the negative impact of forestry remained somewhat unchanged. Current work has tried to address this issue/gap by focusing on quantification and reporting of forestry impacts on water resources in a simplistic language to be understood by all stakeholders and the general public.

The impacts of forestry activities on water quality are a concern for both water resources and forest management. These impacts are of particular concern in watersheds that have multiple stakeholders with different water use interests. The assessment and protection of water resources in these ecosystems is critical to the development of integrated resource management plans. The development of integrated resource management plans is essential for the sustainable development of natural resources.

The assessment of the potential impacts of forestry activities on water resources considers an inventory of potential water uses and users, analysis of historical water quality data from similar (based on ecoregion, geology and proximity) adjacent watersheds and the study of the sensitivity of the watershed to changes in water quality. The development of sampling programs is typically designed to view pre- and post-forestry conditions for the watershed area.

\section{Need for an Assessment Tool}

Pre- and post-forestry water quality data are typically analyzed statistically to gauge the environmental impacts of forestry activities. While this type of analysis is useful to technical audiences such as water resources or forestry staff, it is extremely data-focused and does not inform the watershed stakeholders of environmental impacts. Multiple stakeholders within a watershed require different types of information to deal with their watershed interests. For example, water resources specialists require actual water quality data (i.e., parameters and their values), forestry companies may require information attesting whether best management practices (BMPs) are effective, and the general public and policy makers are usually more interested in general knowledge (i.e., if water is safe to drink, swim or fish). Consequently, in the assessment of the impact of forestry activities it is important to use tools that convert data into information and knowledge that can be understood by all stakeholders.

Recognizing the need for such a tool, it was deemed necessary to find and implement an assessment tool that could capture, evaluate and communicate the impact of forestry activities by converting water quality data into useful information and knowledge. Other desirable features of such a tool would be the ability to evaluate the impact of environmental protection measures such as BMPs; and the ability to predict impacts of forestry activities on water quality based on historical data. When dealing with multiple-use watersheds, water quality needs to be evaluated from the perspective of different water uses and not just from the statistical change perspective. The assessment tool requires the ability to examine water quality data using multiple use criteria that would be useful for different land uses within the watershed. The Canadian Council of Ministers of the Environment Water Quality Index (CCME WQI) was identified as a potential communications tool for these tasks. Though developed primarily as a communications tool, the CCME WQI methodology was adapted to develop a Forestry Water Quality Index (FWQI) calculator that could be used for communication, performance evaluation, and planning and technical data analysis in the forestry sector.

\section{The CCME WQI}

The WQI is based on three measures of variance; scope $\left(\mathrm{F}_{1}\right)$, frequency $\left(\mathrm{F}_{2}\right)$ and amplitude $\left(\mathrm{F}_{3}\right)$. The formulation of the WQI as described in the Canadian Water Quality Index $1.0-$ Technical Report is as follows (CCME 2001):

The measure for scope is $\mathrm{F}_{1}$. This represents the extent of water quality guideline non-compliance over the time period of interest.

$$
\text { [1] } F_{1}=\left(\frac{\text { Number of failed variables }}{\text { Total number of variables }}\right) \times 100
$$

The measure for frequency is $\mathrm{F}_{2}$. This represents the percentage of individual tests that do not meet objectives ("failed tests").

$$
F_{2}=\left(\frac{\text { Number of failed tests }}{\text { Total number of tests }}\right) \times 100
$$

The measure for amplitude is $\mathrm{F}_{3}$. This represents the amount by which failed tests do not meet their objectives. This is calculated in three steps:

\section{Step 1 - calculation of excursion}

Excursion is the number of times by which an individual concentration is greater than (or less than, when the objective is a minimum) the objective.

When the test value must not exceed the objective:

$$
\text { excursion }_{i}=\left(\frac{\text { Failed Test Value }_{i}}{\text { Objective }_{j}}\right)-1
$$

When the test value must not fall below the objective:

$$
\text { excursion }_{i}=\left(\frac{\text { Objective }_{j}}{\text { Failed Test Value }_{i}}\right)-1
$$


Table 1. CCME WQI categorization schema.

\begin{tabular}{lll}
\hline Rank & WQI Value & Description \\
\hline Excellent & $95-100$ & $\begin{array}{l}\text { Water quality is protected with a virtual absence of threat or impairment; conditions very close to natural or } \\
\text { pristine levels; these index values can only be obtained if all measurements are within objectives virtually all } \\
\text { of the time. }\end{array}$ \\
\hline Good & $80-94$ & $\begin{array}{l}\text { Water quality is protected with only a minor degree of threat or impairment; conditions rarely depart from } \\
\text { natural or desirable levels. }\end{array}$ \\
\hline Fair & $65-79$ & $\begin{array}{l}\text { Water quality is usually protected but occasionally threatened or impaired; conditions sometimes depart } \\
\text { from natural or desirable levels. }\end{array}$ \\
\hline Marginal & $45-64$ & Water quality is frequently threatened or impaired; conditions often depart from natural or desirable levels. \\
\hline Poor & $0-44$ & $\begin{array}{l}\text { Water quality is almost always threatened or impaired; conditions usually depart from natural or desirable } \\
\text { levels. }\end{array}$ \\
\hline
\end{tabular}

Step 2 - calculation of normalized sum of excursions

The normalized sum of excursions (nse) is the collective amount by which individual tests are out of compliance. This is calculated by summing the excursions of individual tests from their objectives and dividing by the total number of tests (both those meeting obiectives and those not meeting objectives).

$[5]$

$$
n s e-\frac{\sum_{i=1}^{n} \text { excursion }_{i}}{\text { Number of tests }}
$$

Step 3 - calculation of $\mathrm{F}_{3}$ $\mathrm{F}_{3}$ is calculated by an asymptotic function that scales the normalized sum of the excursions from objectives to yield a range from 0 to 100 .

$$
\mathrm{F}_{3}=\left(\frac{n s e}{0.01 n s e+0.01}\right)
$$

The WQI is then calculated as:

$$
\text { [7] } \mathrm{WQI}=100-\left(\frac{\sqrt{\mathrm{F}_{1}^{2}+\mathrm{F}_{2}^{2}+\mathrm{F}_{3}^{2}}}{1.732}\right)
$$

The WQI values are then converted into rankings by using the categorization scheme presented in Table 1.

\section{Adapting the CCME WQI for the Forestry Sector}

The CCME WQI is primarily a communications tool. In adapting the CCME WQI methodology to develop the FWQI calculator, the role of the CCME WQI was expanded to include planning, performance measurement and data analysis components. The planning component enables forestry personnel to predict the water quality that will be present after forestry activities have taken place and performance measurement allows personnel to establish the effectiveness of best management practices (BMPs). These components were developed solely to address the needs of the forestry sector.
There are many specialized tools, models and protocols available in the forestry sector for planning, performance measurement and data analysis. However, many of these tools and models, due to their inherently technical nature, produce results that are not amenable for communication to the general public and many stakeholders. In light of this, the FWQI was developed as a communication-focused assessment tool that is easy to use and will be an additional tool for forest management personnel (Tobin 2004). It is not to be used as replacement for detailed forestry planning and analysis.

The communication, planning, performance measurement and data analysis capabilities and applications of the FWQI are explained in the following sections through the use of case studies from Newfoundland and Labrador (NL).

\section{Communications application}

The CCME WQI methodology is designed to convert raw data into information and then into knowledge by comparing water quality data with water quality guidelines. The CCME WQI methodology has been implemented in its entirety in the FWQI. The FWQI can be used directly with pre- and postforestry data to derive information on the ranking of a water body for various water uses and on the scope, frequency and magnitude of water quality exceedances. The information determined through these two methods is easily compared and provides a snapshot of the impact of forestry on water quality that is easy to communicate to stakeholders.

Water bodies in watersheds undergoing forest harvesting are often used for a variety of purposes. Thus, in adapting the CCME WQI methodology for the forestry sector, the FWQI was designed to allow the evaluation of water quality datasets against six different water quality guidelines simultaneously. The water quality guidelines used were the CCME Canadian Environmental Quality Guidelines (CCME 2003) for:

- drinking water quality,

- water quality guidelines for the protection of aquatic life,

- water quality guidelines for the protection of agricultural water uses-irrigation, and

- water quality guidelines for the protection of agricultural water uses-livestock.

An overall guideline was also used, which is the most con- 
Table 2. FWQI scores, F1, F2 and F3 values for pre- and post-forestry water quality of Lower Shoal Harbour River.

\begin{tabular}{|c|c|c|c|c|c|c|c|c|c|c|}
\hline & \multicolumn{2}{|c|}{ Overall } & \multicolumn{2}{|c|}{ Drinking } & \multicolumn{2}{|c|}{ Aquatic } & \multicolumn{2}{|c|}{ Irrigation } & \multicolumn{2}{|c|}{ Livestock } \\
\hline & Pre- & Post & Pre- & Post & Pre- & Post & Pre- & Post & Pre- & Post \\
\hline FWQI & $\begin{array}{l}71 \\
\text { Fair }\end{array}$ & $\begin{array}{c}60 \\
\text { Marginal }\end{array}$ & $\begin{array}{l}79 \\
\text { Fair }\end{array}$ & $\begin{array}{l}72 \\
\text { Fair }\end{array}$ & $\begin{array}{c}59 \\
\text { Marginal }\end{array}$ & $\begin{array}{c}48 \\
\text { Poor }\end{array}$ & $\begin{array}{c}100 \\
\text { Excellent }\end{array}$ & $\begin{array}{c}95 \\
\text { Excellent }\end{array}$ & $\begin{array}{c}81 \\
\text { Good }\end{array}$ & $\begin{array}{l}73 \\
\text { Fair }\end{array}$ \\
\hline $\mathrm{F}_{1}$ & 35 & 42 & 19 & 25 & 60 & 58 & 0 & 8 & 8 & 7 \\
\hline $\mathrm{F}_{2}$ & 22 & 29 & 16 & 22 & 34 & 44 & 0 & 2 & 8 & 14 \\
\hline $\mathrm{F}_{3}$ & 29 & 48 & 27 & 36 & 20 & 53 & 0 & 0 & 31 & 43 \\
\hline
\end{tabular}

Table 3. Sample Multiplier Calculation

\begin{tabular}{cccc}
\hline Year & $\begin{array}{c}\text { Turbidity } \\
\text { (annual mean) } \\
\text { Trout Pond }\end{array}$ & $\begin{array}{c}\text { Turbidity } \\
\text { (annual mean) } \\
\text { Control } \\
\text { Watershed }\end{array}$ & \\
\hline 2000 & 0.88 & 0.33 & Multiplier \\
2001 & 0.38 & 0.33 & 1.15 \\
\hline
\end{tabular}

servative parameter guideline from the previous five guidelines listed.

One of the strengths of using the FWQI as a communications tool is that it can be used to understand the nature of water quality exceedances, i.e., if the exceedances affect many parameters (scope; $\mathrm{F}_{1}$ ), if the exceedances occur frequently (frequency; $\mathrm{F}_{2}$ ) or if the exceedances are due to very high concentrations (amplitude; $\mathrm{F}_{3}$ ). This is because the FWQI also provides information on the scope, frequency and amplitude of water quality exceedances. Forestry activity in the Lower Shoal Harbour River watershed began in 1997. Water quality data were available from 1990-1994 and 1998-2001 from a drinking water quality sampling program. There were no samples taken between 1995 and 1997 for this sampling program. Table 2 shows pre- and post-forestry data for Lower Shoal Harbour River as analysed using the FWQI. The FWQI ranks the pre- and post-forestry water quality for simple comparison of scores and also shows the three measures of variance for pre- and post-forestry water quality results. There is a slight decrease in water quality index scores since the start of forestry activities in 1997.

The examination of the measures of variance in Table 2 provides insight into the reasons behind the decrease of water quality results between pre- and post-forestry activities. For example, looking at the protection of aquatic life use, the primary reason for post-forestry scores being lower than preforestry scores is that there is an increase in both the frequency and magnitude of exceedances despite the reduction in scope (the number of affected parameters).

\section{Planning application}

To adapt the CCME WQI methodology so that the FWQI could be used for planning purposes, a methodology for predicting the impacts of forestry on water quality was developed. This methodology is based on the use of historical pre-

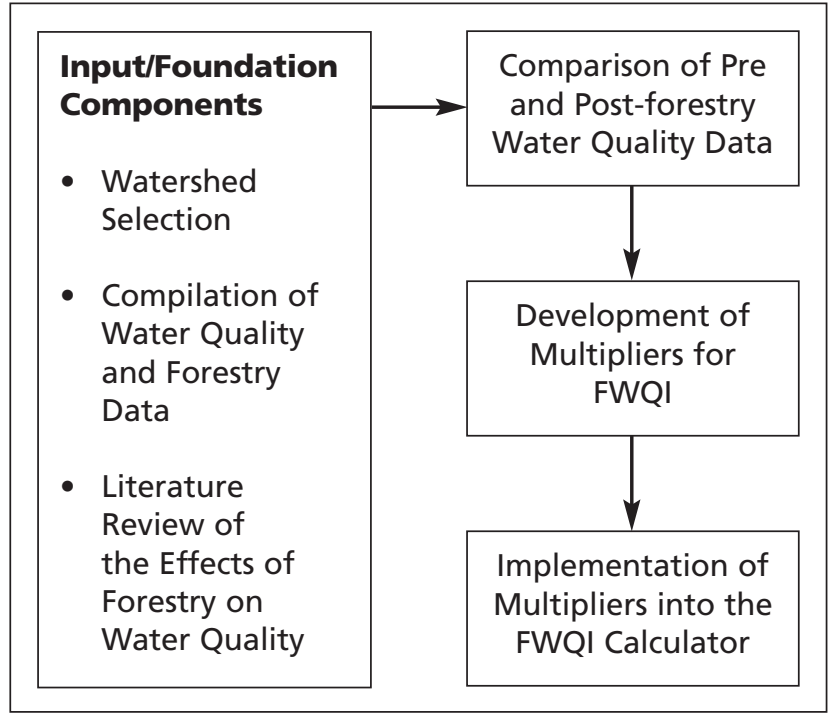

Fig. 1. Steps in adapting the CCME WQI for the forestry sector.

and post-forestry water quality data from similar watersheds. The data are used to predict changes in water quality in the watershed being evaluated for forestry. It works on the assumption that predicted changes in water quality due to future forestry in a watershed of interest would be similar to changes experienced in a similar watershed that have already experienced forestry activities.

The methodology has two distinct components or steps:

- In the first step, control watersheds are identified that are adjacent to the watersheds of interest that have not been subjected to forestry activities. The pre- and post-forestry water quality data from the control watersheds are analysed and compared to identify which water quality parameters were affected by forestry activities and by what factor these parameters increased or decreased between the pre- and post-forestry data.

- In the second step, the same changes identified in step 1 are applied to pre-forestry water quality data from the watershed being evaluated to predict the condition of the post-forestry water quality. Table 3 shows a sample multiplier calculation for Trout Pond.

The yearly averages for the control watershed were calculated and compared with water bodies in the study. All communities were analyzed in this method with all five parameters of interest. Each parameter was then statistically 


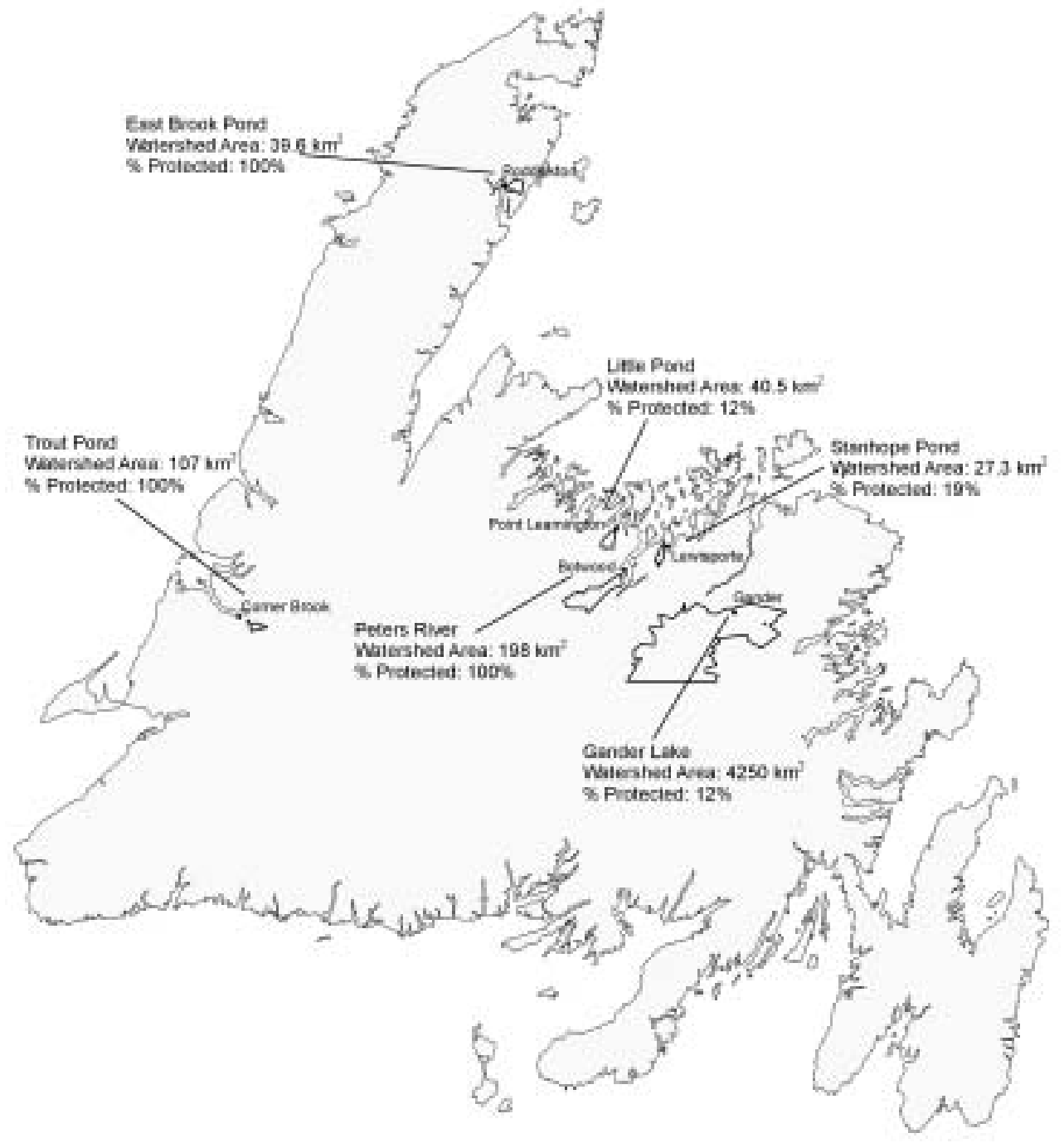

Fig. 2. Selected watersheds and their characteristics.

examined for mean, standard deviation, maximum, minimum and median values for each community using the annual multiplier shown in the fourth column of Table 3 .

To help users of the FWQI in NL, a study was undertaken to identify which water quality parameters were affected by forestry activities and by what multiplicative factor these parameters increased or decreased between the pre- and postforestry data. The results of this study were then incorporated into the FWQI calculator so that users of the FWQI calculator could evaluate the potential impact of forestry on any watershed in NL without having to repeat step one of the methodology.

This study consisted of three distinct initial components as illustrated in Fig. 1.

\section{Input/foundation components}

The first component of the study was the selection of watersheds. This was initiated by selecting a wide variety of watersheds that had been subjected to forestry activities since 1993. The selection of watersheds was focused on the island portion of NL because of large gaps in the water quality data record in Labrador. A selection criterion was developed to ensure that the majority of watershed characteristics in NL were represented. The selection criteria consisted of a complete spectrum of land use (developed areas, transitional areas, and pristine areas); regional representation (western, central, and eastern); and size representation (watersheds varying in size from $7 \mathrm{~km}^{2}$ to $4250 \mathrm{~km}^{2}$ ). Based on these criteria, watersheds were selected for use in the development and testing of the FWQI model (Fig. 2) and are listed in Table 3.

There are nine ecoregions established for NL. This study utilized watersheds within four of these ecoregions. Table 4 lists the study watersheds and their respective ecoregions. The ecoregions that are not represented by these watersheds are typically barren and do not include forest ecosystems, or are in areas where forestry activities are not permitted to take place.

Forestry and water quality data were compiled to be used as input for the development of the model. The quantity of forestry activities that occurred within a watershed was col- 
lected on a yearly basis for the Department of Natural Resources and Corner Brook Pulp and Paper. Water quality datasets (typically taken two to four times annually) were obtained from the Department of Environment and Conservation.

\section{Development of multipliers for FWQI}

A literature review was conducted on the effects of forestry activities on water quality. The water quality parameters that are typically affected by forestry activities are turbidity, dissolved organic carbon (DOC), nutrients (potassium, phosphorus and nitrogen), temperature and dissolved oxygen (DO).

Multiplier values were developed for those parameters that are typically affected by forestry activities as illustrated through the literature review. The multiplier values are used to predict the water quality conditions that will be present after forest harvesting occurs. The current datasets for the water body of interest are used and multiplied by the multiplier factor to determine future water quality. This process is used as the planning component of the FWQI.

Water quality datasets were averaged on a yearly basis for each parameter of interest. All parameters identified in the literature review were examined with the exception of temperature (not applicable to lakes) and DO (no water quality data available). To assess the impacts of forestry activities, water quality data were compared to data from control sites. Control sites are sites that are adjacent to the study sites but that have not been subject to forestry activities. The yearly averages for the control points were compared with the corresponding water body in the study. All six public water supplies were analyzed in this method for all five parameters of interest (turbidity, potassium, phosphorus, nitrogen and DOC). Each parameter was then statistically examined for mean, standard deviation, maximum, minimum and median annual values for each supply.

The recommended value for use as a multiplier value is the mean plus one standard deviation. Adding one standard deviation to the measure of the mean will account for the variation that is present in the datasets. The maximum value, however, should be used if the forestry area is sensitive or if there are other factors that should be considered.

Multipliers were developed for the general overall Newfoundland area (provincial multipliers). These multipliers were developed using the averages of all six water bodies and are presented in Table 5. The multiplier values for each of the study areas in this project (study area multipliers) were also calculated and are presented in Table 6 .

A protocol was developed to assist in the determination of which multiplier set should be utilized to obtain accurate WQI scores for a particular watershed of interest. The appropriate multiplier set is dependent on the location and size of the watershed under consideration. For example, a watershed within the same ecoregion as one of the study areas should be examined first (Table 7). In ecoregions where there are more than one study area within that region, as depicted in the Central Newfoundland Forest ecoregion, a corresponding watershed size should be considered. Results should be determined using this method as well as using the general provincial multipliers (Table 6). The most conservative WQI scores for these two methods should be accepted as the predicted scores for planning purposes.
Table 4. Ecoregion classifications and corresponding watersheds.

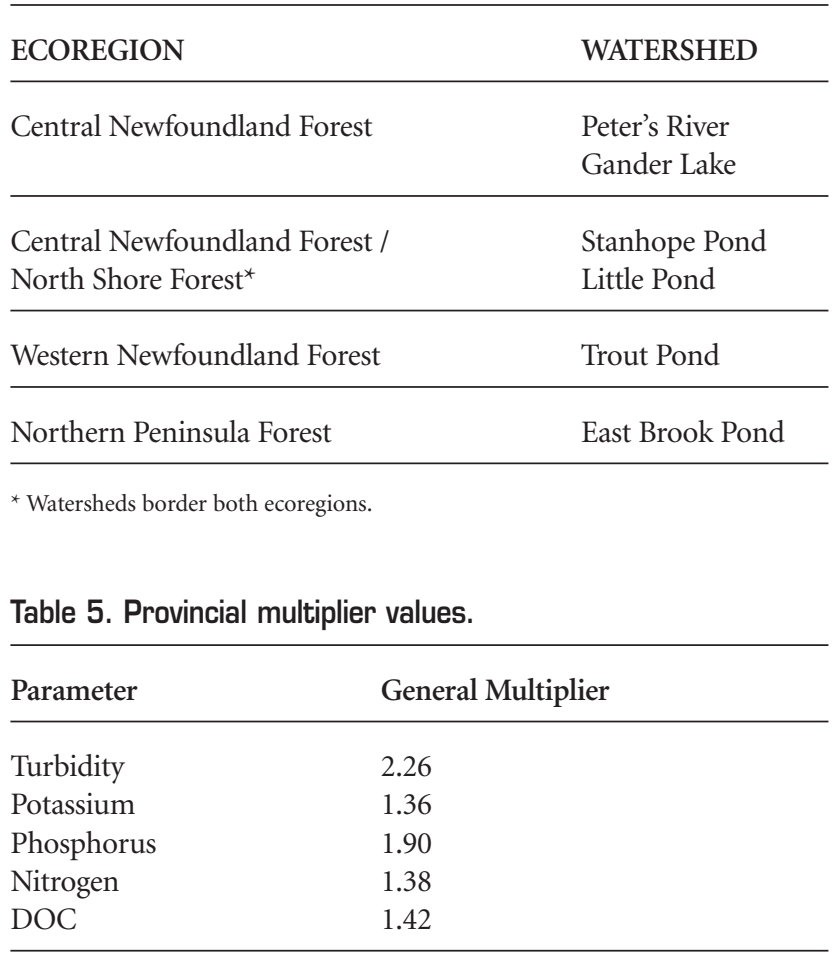

The results for predicting water quality after forestry activities is dependent on the accurate selection of a corresponding watershed. Ideally, each watershed of interest would have its own set of multipliers to accurately represent the predicted water quality. In situations were this is not possible, consideration should be used when selecting a corresponding watershed.

\section{Incorporating multiplier values for planning purposes}

For the prediction of water quality for post-forestry conditions, the developed multipliers were integrated into the calculator. For example, turbidity, phosphorus, potassium, dissolved organic carbon and nitrogen pre-forestry data were multiplied by their respective parameter multipliers (from Table 5 or Table 6) to give a post-forestry dataset for these particular parameters.

Post-forestry turbidity $=($ Pre-forestry turbidity value $) \times$ (Turbidity general multiplier) $1.8=(0.8) \times(2.26)$

The turbidity value at that time would be entered into the calculator as 0.8 Nephelometric Turbidity Units (NTU) for pre-forestry datasets and 1.8 NTU for post-forestry datasets.

Table 7 illustrates the results of the application of the general province and specific watershed multipliers to a preforestry water quality dataset from Little Pond.

The water quality data from Little Pond are from 1987 to 2002. The post-forestry values presented in Table 7 are the FWQI scores that would be expected if forestry activities were to take place in the Little Pond watershed. The FWQI scores obtained using the general and watershed specific multipliers are slightly different, though the rankings do not change. The FWQI scores obtained using the general multipliers are more conservative and consequently these would be accepted as the post-forestry FWQI scores. 
Table 6. Specific watershed multiplier values.

\begin{tabular}{lcccccc}
\hline Parameter & Peter's River & Trout Pond & Gander Lake & Stanhope Pond & Little Pond & East Brook Pond \\
\hline Turbidity & 1.84 & 2.45 & 1.92 & 2.19 & 1.91 & 0.67 \\
Potassium & 1.13 & 1.29 & 1.44 & 1.25 & 1.85 & 0.59 \\
Phosphorus & 1.63 & 3.90 & 2.58 & 1.04 & 1.33 & 1.27 \\
Nitrogen & 1.66 & 1.39 & 1.34 & 1.49 & 1.78 & 0.89 \\
DOC & 1.67 & NA & 1.39 & & & \\
\hline
\end{tabular}

Table 7. Pre- and post-forestry water quality data for Little Pond using FWQI.

\begin{tabular}{|c|c|c|c|c|c|}
\hline & Overall & Drinking & Aquatic & Irrigation & Livestock \\
\hline Pre-forestry & $\begin{array}{c}82 \\
\text { Good }\end{array}$ & $\begin{array}{c}88 \\
\text { Good }\end{array}$ & $\begin{array}{l}75 \\
\text { Fair }\end{array}$ & $\begin{array}{c}94 \\
\text { Good }\end{array}$ & $\begin{array}{c}89 \\
\text { Good }\end{array}$ \\
\hline $\begin{array}{l}\text { Post-forestry } \\
\text { (General Multipliers) }\end{array}$ & $\begin{array}{l}76 \\
\text { Fair }\end{array}$ & $\begin{array}{c}80 \\
\text { Good }\end{array}$ & $\begin{array}{l}68 \\
\text { Fair }\end{array}$ & $\begin{array}{c}87 \\
\text { Good }\end{array}$ & $\begin{array}{c}83 \\
\text { Good }\end{array}$ \\
\hline $\begin{array}{l}\text { Post-forestry } \\
\text { (Specific Watershed } \\
\text { Multipliers) }\end{array}$ & $\begin{array}{l}78 \\
\text { Fair }\end{array}$ & $\begin{array}{c}83 \\
\text { Good }\end{array}$ & $\begin{array}{l}71 \\
\text { Fair }\end{array}$ & $\begin{array}{c}90 \\
\text { Good }\end{array}$ & $\begin{array}{c}86 \\
\text { Good }\end{array}$ \\
\hline
\end{tabular}

\section{Performance measure component}

For the protection of water resources, BMPs are often implemented in forestry activity areas. The assessment of the effects of BMPs is critical in the management of forest harvesting. To implement such a feature in the FWQI calculator, a pilot study was conducted to evaluate how the CCME WQI methodology could be used to evaluate the impacts of BMPs. A complication in the analysis of the impact of BMPs is that the positive effect of any given BMP on water quality is not immediately visible in a watershed and consequently if a number of BMPs are implemented their effects will be spread out over time.

The application of the FWQI as a performance measurement tool was assessed through analysis of the Gander Lake protected public water supply area. The implementation of BMPs in the Gander Lake watershed began in 1996 in accordance with recommendations from an Environmental Protection Plan. Data from 1993 to 2002 were used for the analysis. The data were split into a pre-BMP and post-BMP period, but since the effects of BMPs are not immediate a rolling window was used to assess when the effect of BMPs was being reflected in water quality. The use of a rolling window resulted in four sets of pre-BMP and post-BMP data as shown in Table 8 . The WQI score was calculated for the preBMP and post-BMP data for each set and compared.

In dataset number 3, the post-BMP FWQI scores started showing an improvement over the pre-BMP FWQI scores. From examining the FWQI scores for all sets, it appears that the effects of the BMPs were reflected in the water quality from 1998 onwards. If the BMPs were not effective, the FWQI scores would show little or no change within the time frames.
This analysis allows the forestry sector to determine whether the existing practices are meeting the goals and objectives set for the BMPs.

\section{Data analysis component}

In addition to being a communications and summarizing tool, the FWQI calculator has built-in functionality for data analysis. This data analysis capability is a by-product of the CCME WQI methodology as it works to convert raw water quality data into insightful and meaningful information.

Seasonal variation of water quality is critical to forest management planning due to sedimentation and water level issues. Stanhope Pond, used by Lewisporte as a public water supply, has water quality data that were collected through all four seasons between 1986 and 2002. Table 9 depicts the seasonal variation of the water body through examination of FWQI values.

A comparison of the $\mathrm{F}_{1}, \mathrm{~F}_{2}$, and $\mathrm{F}_{3}$ values in Table 9 indicates that the scope, frequency, and amplitude, which are used to calculate the FWQI score, vary significantly between the seasons. The F1 (scope) is the number of parameters that do not meet established guidelines, F2 (frequency) is the number of times a parameter does not meet established guidelines, and F3 (amplitude) is the amount by which a parameter value exceeds an established guideline. This type of analysis is particularly useful for planning and management of the harvesting start date and the time period of activity that can occur within a particular watershed.

The FWQI has additional data analysis features such as summary statistics, sensitivity analysis, and comparison of upstream and downstream datasets. The data analysis or 
Table 8. Pre and post-BMP FWQI scores using a rolling window.

\begin{tabular}{|c|c|c|c|c|c|}
\hline Datasets & Time Frame & \# of parameters & $\begin{array}{c}\text { \# of } \\
\text { samples }\end{array}$ & FWQI Value & FWQI Ranking \\
\hline \multirow[t]{2}{*}{1} & 1993-1996 & 16 & 8 & 84 & Good \\
\hline & 1997-2002 & 16 & 26 & 82 & Good \\
\hline \multirow[t]{2}{*}{2} & 1993-1997 & 16 & 11 & 84 & Good \\
\hline & 1998-2002 & 16 & 23 & 83 & Good \\
\hline \multirow[t]{2}{*}{3} & 1993-1998 & 16 & 19 & 82 & Good \\
\hline & 1999-2002 & 16 & 15 & 86 & Good \\
\hline \multirow[t]{2}{*}{4} & 1993-1999 & 16 & 25 & 82 & Good \\
\hline & 2000-2002 & 16 & 9 & 88 & Good \\
\hline
\end{tabular}

Table 9. Seasonal variation of Stanhope Pond watershed.

\begin{tabular}{|c|c|c|c|c|c|}
\hline & FWQI & Category & $\begin{array}{c}\mathrm{F}_{1} \\
\text { (Scope) }\end{array}$ & $\mathrm{F}_{2}$ (Frequency) & $\mathrm{F}_{3}$ (Amplitude) \\
\hline Fall & 79 & Fair & 21 & 14 & 26 \\
\hline Spring & 71 & Fair & 33 & 16 & 33 \\
\hline Summer & 78 & Fair & 25 & 18 & 21 \\
\hline Winter & 87 & Good & 12 & 10 & 17 \\
\hline
\end{tabular}

technical analysis component of the FWQI can be used for indepth analysis when required for report writing and management purposes. This tool would be applicable for forest management in developing the Five Year Operating plans that are required in NL.

\section{Conclusions}

Within NL, the multipliers will be updated as new pre- and post-forestry water quality data are made available through focused monitoring programs. The water quality data used in this study were pre-existing data collected from water supplies in watersheds affected by forestry. The water quality data did not have seasonal coverage and this did not allow for analysis of seasonal variation. To accurately capture the effect of forestry activities, water quality data need to be collected using a monitoring program specifically designed to capture these effects. This would preferably also involve the use of continuous water quality monitoring equipment.

As demonstrated in the various case studies presented in this paper, the FWQI is an excellent communication-based assessment tool that can capture, evaluate and communicate the impact of forestry activities on water bodies by converting water quality data into useful information and knowledge. It is a tool that is easy to use, and is based on a nationally approved methodology for communicating water quality data. It is a versatile tool that has distinct communication, planning, performance measurement and data analysis capabilities.
The FWQI's communication, performance measurement and data analysis capabilities can be used directly wherever there are water quality data and corresponding guidelines for comparison of data. The planning component described, however, is specific to the province of NL since the multipliers are based on historical datasets from the province. Using the methodology to derive multipliers presented in this paper, the planning component functionality could be developed for any province or jurisdiction.

\section{Acknowledgements}

We would like to acknowledge the tri-party agreement between NL Forest Services, Western Newfoundland Model Forest and the Department of Environment and Conservation for the funding for this project. We would also like to acknowledge Jennifer Bonnell for her advice in editing this paper.

\section{References}

CCME. 2001. Canadian water quality guidelines for the protection of aquatic life: Canadian Water Quality Index 1.0 Technical Report. In Canadian environmental quality guidelines. 1999, updated 2001. Winnipeg, Manitoba.

CCME. 2003. Canadian Water Quality Guidelines for the Protection of Aquatic Life, Chapter 4. In Canadian environmental quality guidelines. 1999, updated 2003. Winnipeg, Manitoba.

Tobin, A. 2004. Forestry Water Quality Index (FWQI). Department of Natural Resources, Department of Environment and Conservation and Western Newfoundland Model Forest. Newfoundland and Labrador. 